\title{
The histopathology and ultrastructure of steatitis affecting common dab Limanda limanda
}

\author{
G. S. Begg *, D. W. Bruno, A. H. McVicar \\ Fisheries Research Services Marine Laboratory, PO Box 101, Victoria Road, Aberdeen AB11 9DB, United Kingdom
}

\begin{abstract}
This study presents a new description, based on histopathological and ultrastructural studies, of a disease affecting the common dab Limanda limanda (L.). The condition can be recognised by the presence of multiple orange or yellow lesions in the pterygophorial region of the fish. The principal histopathological features are necrosis of fat cells, extensive macrophage infiltration leading to the formation of granulomatous structures, and the accumulation of lipopigment by lipid peroxidation. Based on this description, the condition has been diagnosed as steatitis. Although pathology associated with lipid peroxidation is the dominant characteristic of the lesions examined, it is proposed that this process is secondary to necrosis of the adipose tissue. The aetiology is discussed in the light of these observations. In addition, the first record of this condition affecting long rough dab Hippoglossoides platessoides (Fabricius) is made.
\end{abstract}

KEY WORDS: Steatitis · Fat cell necrosis - Macrophage infiltration - Lipid peroxidation · Common dab Limanda limanda

\section{INTRODUCTION}

A pathological condition affecting common dab Limanda limanda (L.) characterised by the presence of orange or yellow lesions has been recognised for at least 10 yr (A.H.M. unpubl. data) and has been described provisionally as a multiple hypodermal lipoma (Bruno et al. 1991). The condition is known to occur in dab populations from the Firth of Forth, Moray Firth and Orkney areas of the North Sea (Bruno et al. 1991). In a recent study, the overall prevalence on the east coast of Scotland was found to be $6.9 \%$ (Begg 1994). During a preliminary histopathological examination of this condition a number of additional observations were made that appeared to extend the description made by Bruno and co-workers. The present study

\footnotetext{
- Present address: Biomathematics and Statistics Scotland, Scottish Crop Research Institute, Invergowrie, Dundee, DD2 5DA, UK. E-mail: grahamb@bioss.sari.ac.uk
}

reports the results of a histopathological and ultrastructural investigation that was conducted with the aim of clarifying the nature of this disease. In addition, the first record of this disease affecting long rough dab Hippoglossoides platessoides (Fabricius) is made.

\section{MATERIALS AND METHODS}

Histology. Tissue samples for light microscopy were collected from common dab from 3 sites on the east coast of Scotland: the St. Abb's sewage sludge disposal site $\left(56^{\circ} 04.5^{\prime} \mathrm{N}, 02^{\circ} 07.25^{\circ} \mathrm{W}\right)$, an adjacent reference site $\left(56^{\circ} 04^{\prime} \mathrm{N}, 02^{\circ} 02^{\prime} \mathrm{W}\right)$, and Burghead Bay in the Moray Firth $\left(57^{\circ} 42^{\prime} \mathrm{N}, 03^{\circ} 31^{\prime} \mathrm{W}\right)$. Sampling took place between February 1990 and April 1992. In most cases, sampling of the tissue was typically carried out within $3 \mathrm{~h}$ after capture of the fish. Areas of affected tissue were removed and fixed in $10 \%$ buffered formol saline for at least $24 \mathrm{~h}$. Fixed samples were decalcified in double strength Perenyi's fluid, processed, and paraf- 
fin embedded. Sections were cut at $5 \mu \mathrm{m}$ and stained with Harris's haematoxylin and eosin (H\&E). Selected sections were also stained by periodic acid Schiff's (PAS), modified Ziehl-Neelsen, Schmorl's, sudan black $B$, Gram, and oil red O. The application of the oil red O technique to paraffin-embedded material identifies lipids that, through some modification, are resistant to extraction by ethanol during the processing associated with the preparation of paraffin sections. All staining techniques followed Bancroft \& Stevens (1985). A total of 372 samples were examined.

During a survey of the disease conditions of common dab (Begg 1994), lesions similar to the ones of the common dab were incidentally observed in long rough dab. To confirm this observation, samples from 8 long rough dab were processed as above and examined histologically, Sections were stained with H\&E only.

Electron microscopy. Live common dab were collected from Burghead Bay, in the Moray Firth, Scotland, and Stonehaven Bay, Aberdeenshire, Scotland, and maintained in aquaria at the Fisheries Research Services Marine Laboratory, Aberdeen. The fish were killed and lesions were teased out from surrounding tissue under a binocular microscope. Small pieces of the lesions (ca $1 \mathrm{~mm}^{3}$ ) were immediately fixed in $2.5 \%$ gluteraldehyde in Millonig's buffer for 1 h at room temperature. Fixed samples were transferred to fresh buffer for $1 \mathrm{~h}$ at room temperature, followed by fresh buffer overnight at $4^{\circ} \mathrm{C}$. The samples were post-fixed in $1 \%$ osmium tetroxide, dehydrated in graded ethanol and propylene oxide, and embedded in Agar 100 resin. Ultrathin sections were cut on a LKB ultramicrotome (LKB 8800 Ultratome III), stained with uranyl acetate and lead citrate, and examined under a Hitachi $\mathrm{H}-300$ electron microscope.

\section{RESULTS}

\section{Gross appearance}

The lesions typically appeared as multiple yellow or orange spots in the pterygophorial region on the ventral surface of the fish. Some small lesions appeared white or cream. The lesions varied in size from minute speckles that were at the limit of resolution by unaided eye to those that involved the entire pterygophorial area. In some instances, the more extensive lesions were accompanied by melanisation of the skin and, in others, by haemorrhagic ulceration (Fig. 1). The lesions of the long rough dab were similar to those of the common dab.

\section{Light microscopy}

The lesions of the common dab exhibit necrosis of fat cells and foci of macrophages situated principally

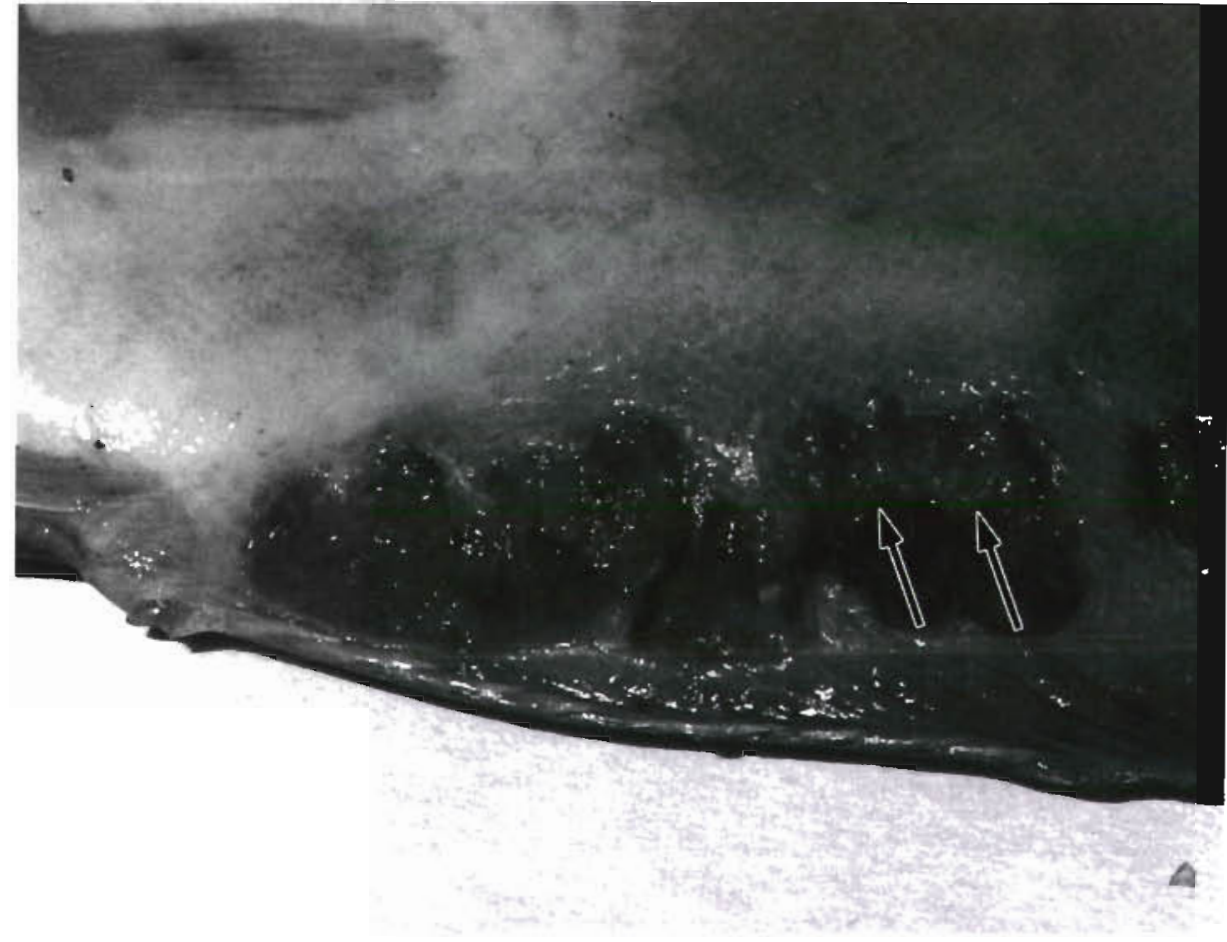

Fig. 1. Limanda limanda. Extensive steatitis lesion (arrows) and surrounding haemorrhagic ulceration 
Fig. 2. Limanda limanda. Macrophages $(M)$ at varying stages of necrosis demonstrating pycnotic nuclei and numerous refractile inclusions. H\&E, scale bar $=100 \mu \mathrm{m}$

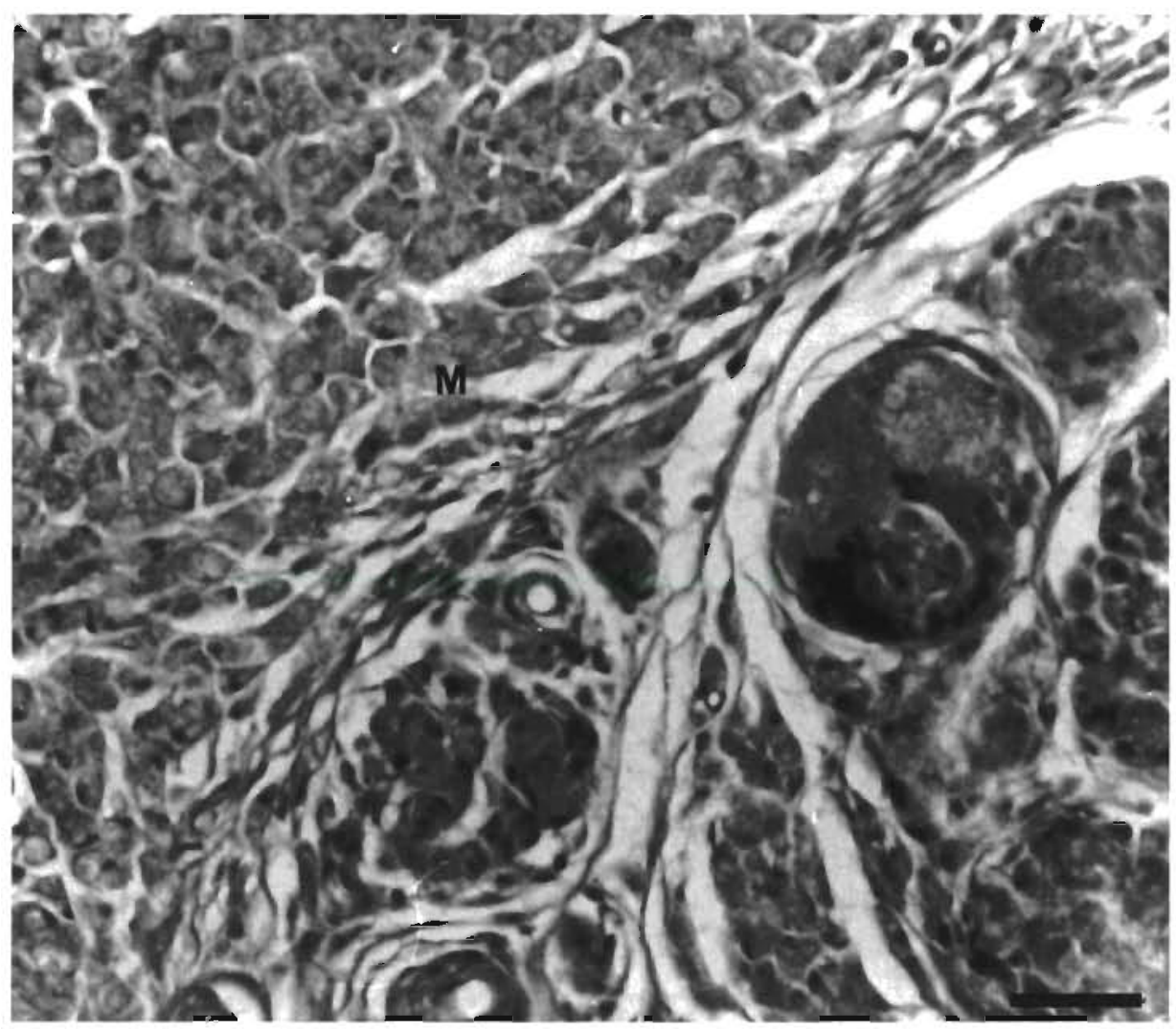

within the sub-dermal and intermuscular adipose tissue. In the smallest lesions the macrophages were situated within the interstitial areas of the adipose tissue. In the more extensive lesions, necrotic fat cells were replaced by large masses of macrophages. The macrophage nuclei were typically small with offset nucleoli. In some cases, the nuclei were pyknotic and there were areas in which the macrophages appeared necrotic (Fig. 2). The macrophage cytoplasm contained numerous granular and refractile inclusions, and occasionally melanin inclusions.

The intracellular granules and refractile droplets of the macrophages were identified as lipopigment, staining positively by sudan black B, modified ZiehlNeelsen for acid-fast material, and oil red $\mathrm{O}$ methods, but negatively by Schmorl's technique. The intracellular granules also reacted positively to PAS. Both types of inclusion exhibited autofluoresence when tissue smears were viewed under ultraviolet light with exciter filter BG12 and a barrier filter of $490 \mu \mathrm{m}$.

The macrophages showed varying degrees of organisation, including the formation of granuloma-type structures. Many of the granulomas consisted of a lacuna surrounded by 1 or several organised layers of cells and collagen (Fig. 3). The cells were predominantly of 1 type: they possessed granular cytoplasmic inclusions similar to those described from the free macrophages. This, in addition to their granulomaforming behaviour, suggests that these cells were also macrophages. However, they differed from the free macrophages in that they did not possess refractile cytoplasmic inclusions, were not necrotic, and appeared to be active showing signs of pseudopodia. Other granulomas that took the form of encysted macrophages surrounded by epithelioid type cells and collagen were also frequently observed (Fig. 3). The macrophages associated with these showed degrees of necrosis, which varied within and between granulomas. Necrosis was often greatest in the centres of the granulomas, while active macrophages were evident at the periphery. An intermediate morphology was also evident in some granulomas. These posessed lacunae of varying sizes positioned centrally with macrophages surrounding them. A third type of granuloma was also observed and distinguished from the others by the presence of a clear, colourless, or brown refractile material (Fig. 4). This material was identified as lightly oxidised lipopigment, exhibiting the same staining characteristics as the lightly oxidised lipopigment macrophage inclusions. The walls of these structures were almost exclusively composed of epithelioid-like cells and collagen.

A number of samples demonstrating extensive macrophage infiltration and granuloma formation also 

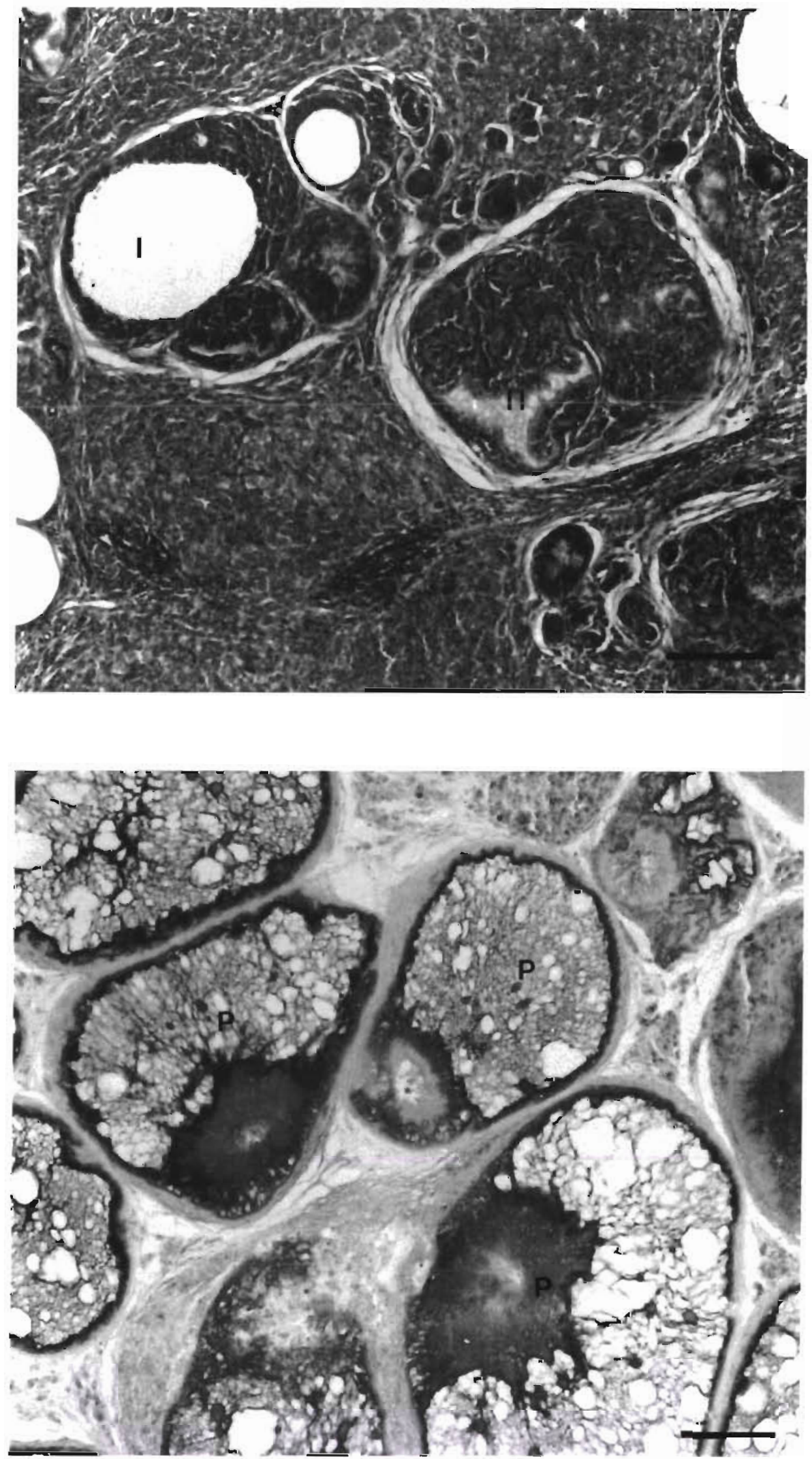

Fig. 3. Limanda limanda. Cellular organisation in steatitis lesion showing characteristic granuloma morphology; lacunae surrounded by several layers of active macrophages (I) and encysted macrophages surrounded by epithelioid cells and collagen (II). H\&E, scale bar $=100 \mu \mathrm{m}$
Fig. 4. Limanda Limanda. The third type of granuloma, showing lipopigment $(\mathrm{P})$ encapsulated by epithelial type cells and collagen. Oil red $\mathrm{O}$, scale bar $=$ $100 \mu \mathrm{m}$ 
exhibited necrosis of the surrounding muscle tissue, including the complete loss of muscle and its replacement by macrophages. In some instances, lesions also possessed areas of collagen deposition, including what appeared to be remnants of granulomas. These areas were devoid of fat cells and macrophages but could be found adjacent to 'active' lesions. Infiltration of lesions by cells other than macrophages, including lymphocytes and eosinophilic granular cells was observed. This was restricted to large lesions with extensive macrophage involvement and was frequently observed in areas of collagen deposition as described above.

Histologically, the lesions of the long rough dab demonstrate all of the features found in the common dab.

\section{Electron microscopy}

Electron microscopy demonstrated that the lesions were dominated by a cell type with a light and dark form (Fig. 5). The light cells possessed eccentrically positioned nuclei with peripheral and central heterochromatin (Fig. 6). The cytoplasm contained numerous electron-dense granules and membrane-bound droplets of variable electron-density some of which had electron-dense rings at their periphery (Fig. 6). The cytoplasmic granules were variable in size with heterogenous contents consisting of granular material, droplets of varying electron density, electron-dense membranous material, and electron-lucent fibrous areas. Similar material was also evident in membranebound structures that had an elongate, convoluted profile in cross section (Fig. 7). Mitochondria were visible in the majority of the light cells; they were swollen and the cristae were often indistinct, and where visible these were tubular (Fig. 7). Other cytoplasmic organelles were evident, including endoplasmic reticulum and golgi apparatus (Fig. 7). The remaining cytoplasmic material was electron-lucent, granular, and in general had a 'frothy' appearance. The cellular membrane was indistinct and cytoplasmic material was extruded from the surface of the cells, suggesting that they were necrotic.

The dark cells were similar to the light cells in size and shape. Their nuclei were more electron-dense within the interchromatin area than those of the light cells, as was the cytoplasmic material which gave rise to the light/dark dichotomy (Fig. 8). In all other respects these cells appeared to be similar to the light cells and again appeared necrotic.

It is clear from the numerical dominance of the light and dark cells that they correspond to cells that were identified by light microscopy as macrophages. The morphological characteristics observed by electron microscopy were consistent with this classification. These included the presence of granules and lipid droplets which were evident as granular lipopigment and refractile inclusions at the light microscope level.

Certain features consistent with the granulomatous structures described by the light microscopy were also identified by electron microscopy. These included the
Fig. 5. Limanda limanda. Light (small arrows) and dark (large arrows) macrophage type cells associated with steatitis lesions. Scale bar $=2 \mu \mathrm{m}$

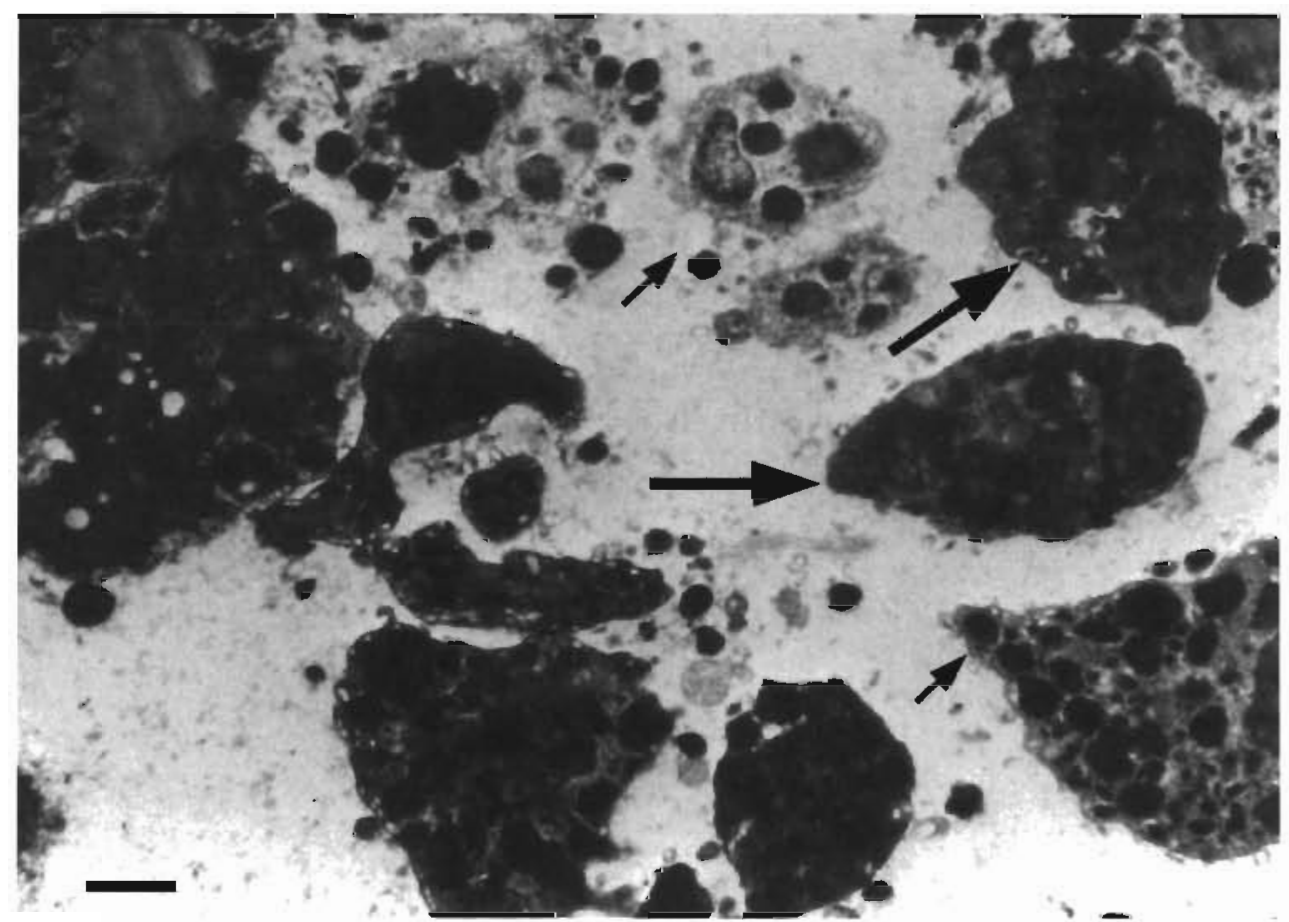




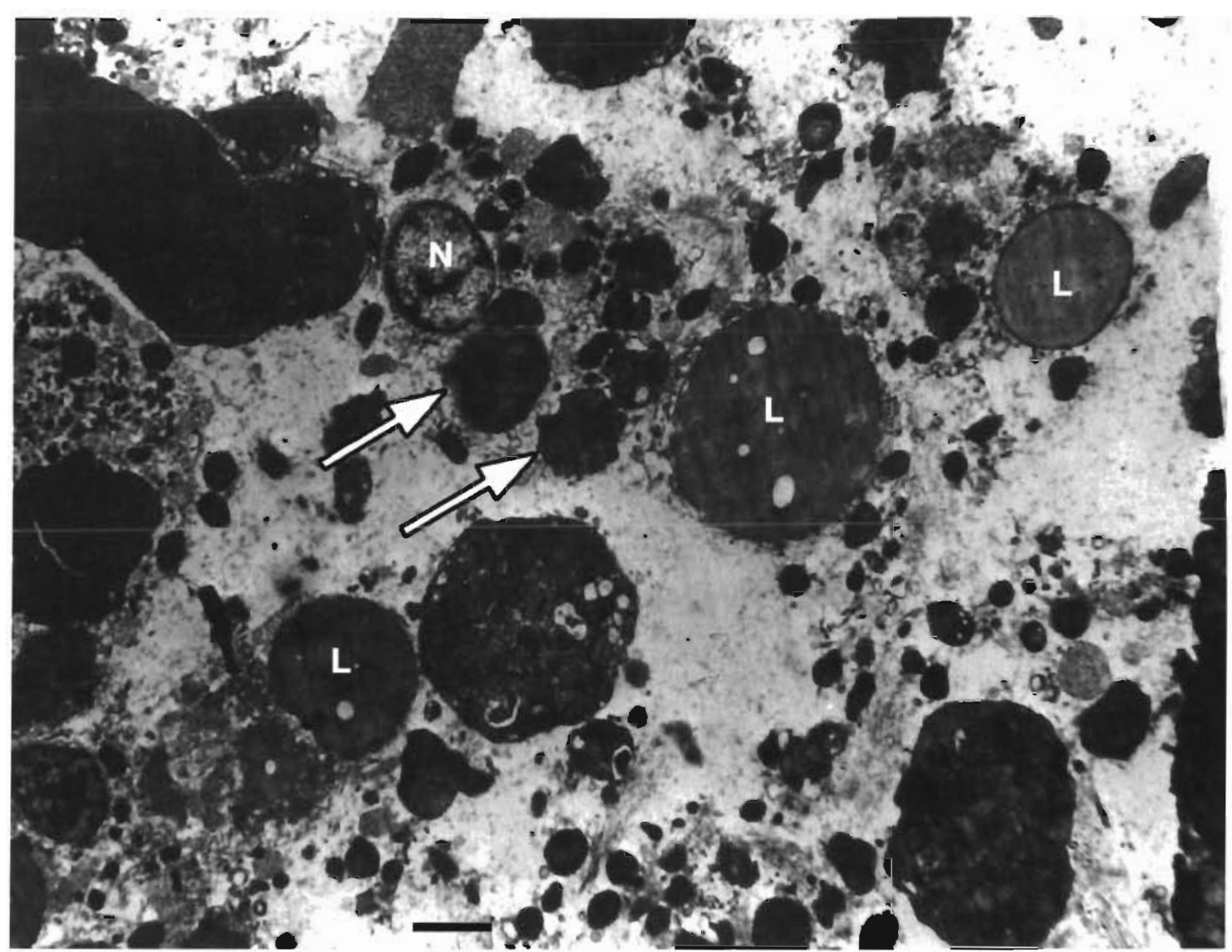

Fig. 6. Limanda limanda. Necrotic light macrophages with nucleus (N), cytoplasmic granules (arrows) and lipid like droplets (L), one of which has an electron-dense perimeter. Scale bar $=2 \mu \mathrm{m}$

presence of activated macrophages surrounding electron-lucent lipid-like material (Fig. 9) and the attachment of free macrophages to lipid droplets (Fig. 10).

Areas of cellular debris were associated with the lesions and consisted of granular cytoplasmic material, nuclei, swollen mitochondria, numerous lipopigment granules, lipid droplets (some with dense rings at the periphery) and collagen fibres. Additional features found within the cell debris were electron-dense structures that were convoluted in form and similar in ultrastructure to the lipopigment granules. Situated at the periphery of the lesions were large areas of extracellular lipid. Associated with this were fibroblasts, lymphocytes and macrophages. The latter were much smaller than those associated with the lesion proper and they did not possess lipopigment granules. Fat cells were also present at the edge the lesions; they were fully differentiated and possessed all the characteristics of this cell type with single, large lipid droplets surrounded by a thin pellicle of cytoplasm and the nucleus displaced to the periphery of the cell. These cells possessed ovoid mitochondria and appeared to be healthy. The adipose tissue was well vascularised.

\section{DISCUSSION}

In their description of a disease condition affecting common dab, Bruno et al. (1991) noted its necrotic and inflammatory nature and described a proliferation of 'encapsulated, greatly distended fat cells'. Based on these findings the condition was described as lipoma (Bruno et al. 1991). In the present study, observations of a larger number of samples of the same condition have shown the principal histopathological characteristics to be: fat cell necrosis, inflammation dominated by macrophages leading to granuloma formation, and the accumulation of lipopigment. These observations are not consistent with a diagnosis of lipoma and it is believed that the 'distended fat cells' described by Bruno et al. (1991) were, in fact, structures similar to the lipopigment-containing granulomas described in the present study. In response to these results we suggest that the term steatitis be adopted to describe the condition. The use of this term, which simply means inflammation of fat tissue, reflects the central role of macrophage infiltration in the pathology, without implying an aetiology. 


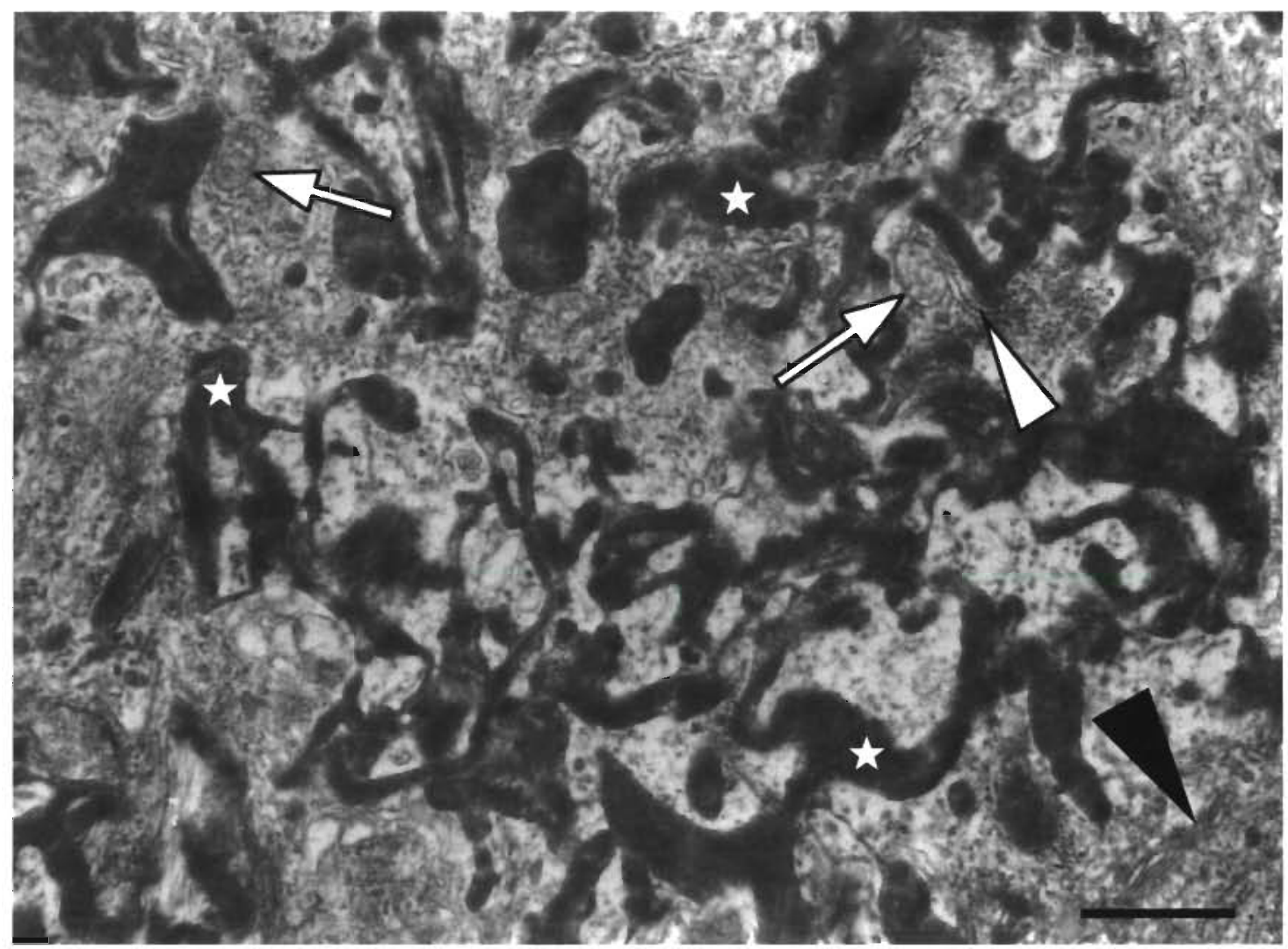

Fig. 7. Limanda limanda. Cytoplasm of light macrophage demonstrating individually membrane-bound elongate-convoluted structures (stars), golgi apparatus (black arrowhead), rough endoplasmic reticulum (white arrowhead), and mitochondria (white arrows). Scale bar $=1 \mu \mathrm{m}$

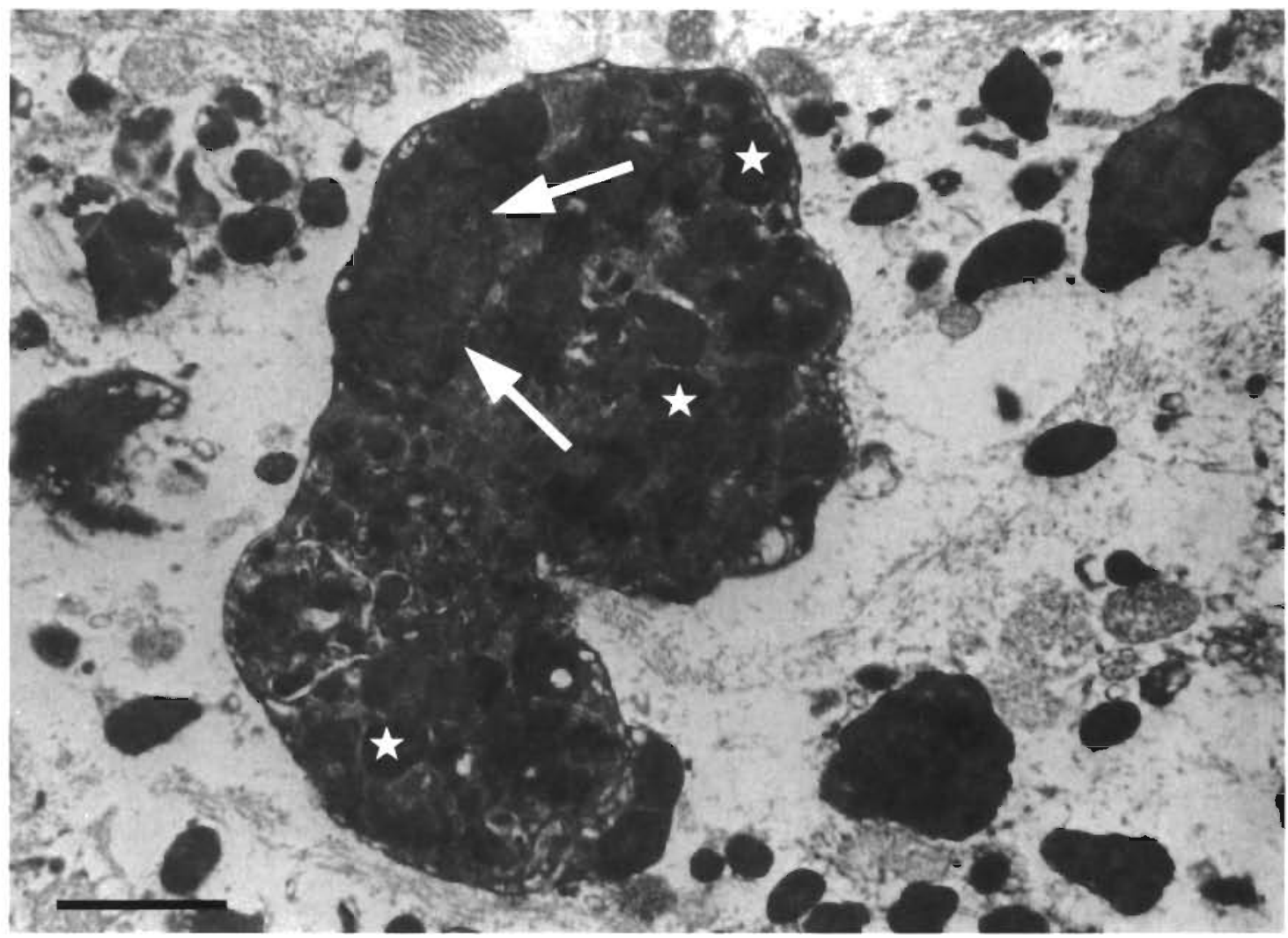

Fig. 8. Limanda limanda. Dark macrophage with eccentrically positioned nucleus (arrows), cytoplasmic granules (stars) and electron-dense granular cytoplasm. Scale bar $=2 \mu \mathrm{m}$ 


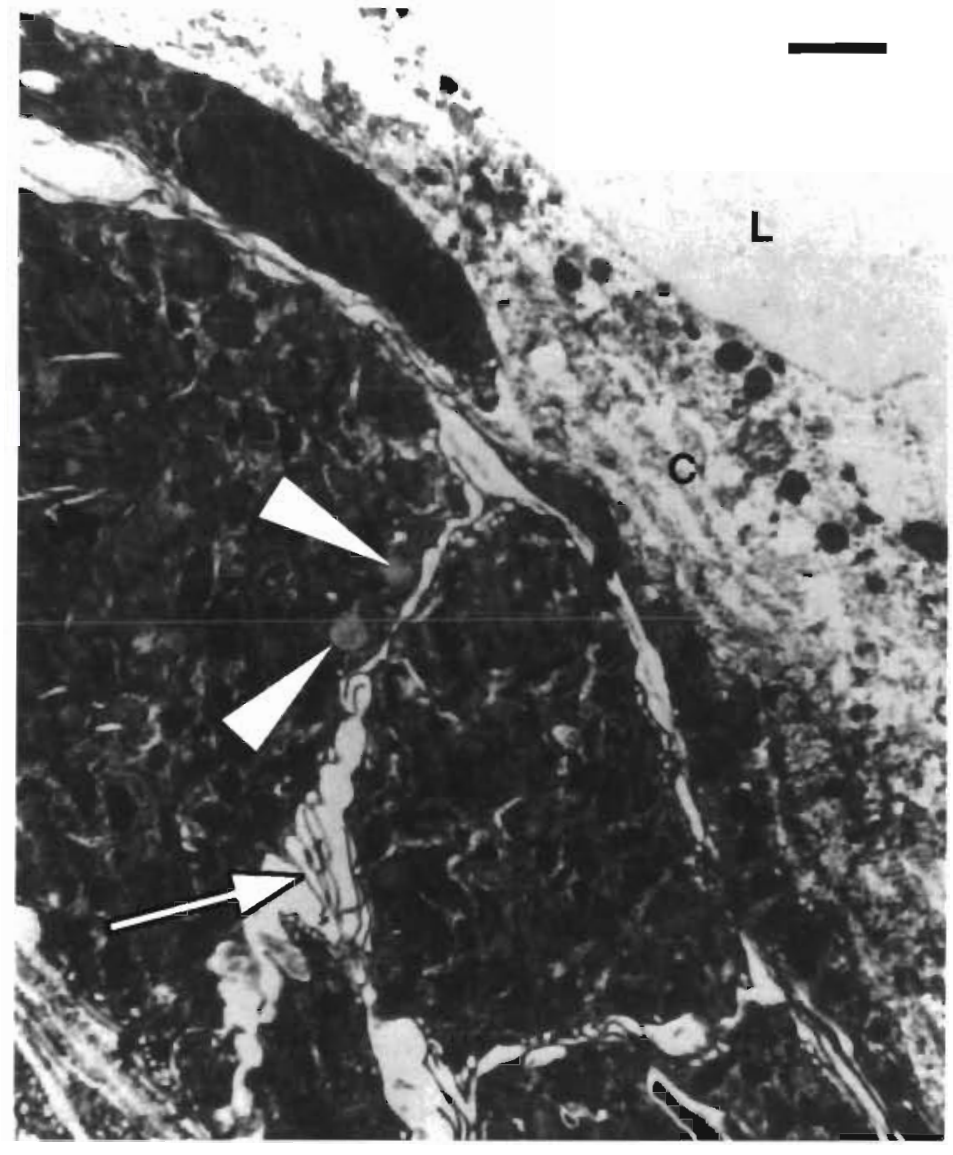

Fig. 9. Limanda limanda. Activated macrophages with pseudopodia (arrow), lipid droplets (arrowheads), and numerous cytoplasmic granules surrounding lipid-like material (L). Areas of collagen and cell debris (C) are also evident. Scale bar $=2 \mu \mathrm{m}$

The pigment associated with the lesions was identified as lipopigment by its resistance to extraction during paraffin embedding, its apolarity, autoflouresence, and acid resistance (Bancroft \& Stevens 1985, Pearse 1985). The negative Schmorl's reaction indicates that it is a lightly oxidised lipopigment (Bancroft \& Stevens 1985). Lipopigments are ubiquitous and have been identified in many tissues in which their accumulation has been associated with a wide range of disease conditions (e.g. human ceroid lipofuscinosis, Goebel 1997; pancreas disease in salmonid fish, Raynard et al. 1991; yellow fat disease, Wada et al. 1991) and also ageing (Dalefield et al. 1987, Hammer \& Karakiri 1988). The ultrastructure of the granular and elongate-convoluted lipopigment bodies identified in the present study is similar to previous descriptions of lipopigment ultrastructure (Lange \& Schropp 1985, Ghadially 1988, Elleder 1991). The simultaneous occurrence of different morphological forms of lipopigment has also been observed (Kimura \& Goebel 1987). The electron-dense rings present at the periphery of lipid droplets were not observed by light microscopy and consequently could not be identified as lipopigment. However, similar features in atherosclerotic plaques have been identified as lipopigment (Mitchison et al. 1990).

The consensus has developed that lipopigments are the product of lipid peroxidation and the co-polymerisation of proteins (Pearse 1985, Jolly \& Dalefield 1990). More recent evidence has shown that, in a group of conditions known as the ceroid-lipofuscinoses, the accumulation of lipopigment may be due to an abnormality in the storage and breakdown of proteins (Jolly \& Dalefied 1990). However, as macrophages are known to have the capacity to produce lipopigments by lipid peroxidation (Maeba et al. 1990), their extensive involvement in the pathology of this condition is consistent with lipid peroxidation having taken place. The extensive necrosis of cells and the ready availability of lipids on which the oxidative process may act are further evidence in favour of lipid peroxidation.

Once lipid peroxidation has been initiated, the process is likely to accelerate as a result of the production of organic peroxides, the liberation of lipids, free radicals and enzymes from fat cells, and the release of free radicals from necrotic macrophages. This provides the conditions necessary for the extracellular oxidation of lipids and is probably responsible for the production of extracellular lipopigments. The extracellular lipopigments were morphologically similar to those described from a number of diseases by Elleder (1991), who also proposed that they arose directly by lipid peroxidation from the cellular debris.

The formation of granulomas in association with the accumulation of lipopigments is known to occur, and ceroid granulomas have been described from a variety of tissues (e.g. uterine ceroid granuloma, Al Nafussi et al. 1992; oral ceroid granuloma, Triantafyllou 1996). In the present study, the examination of a large number of lesions led to the observation of a variety of granulomatous structures. Those exhibiting 'healthy', activated macrophages surrounding a lacuna appear to be a response to extracellular lipid, the lipid having been extracted during the tissue-processing procedure. In other granulomas similarly healthy macrophages were evident at the periphery but the granulomas were filled, entirely in some cases, by macrophages at varying stages of necrosis, which are likely to have been the stimulus for the formation of the granulomas. The necrosis of the encysted macrophages would lead to the release of lipopigment; this is consistent with the 


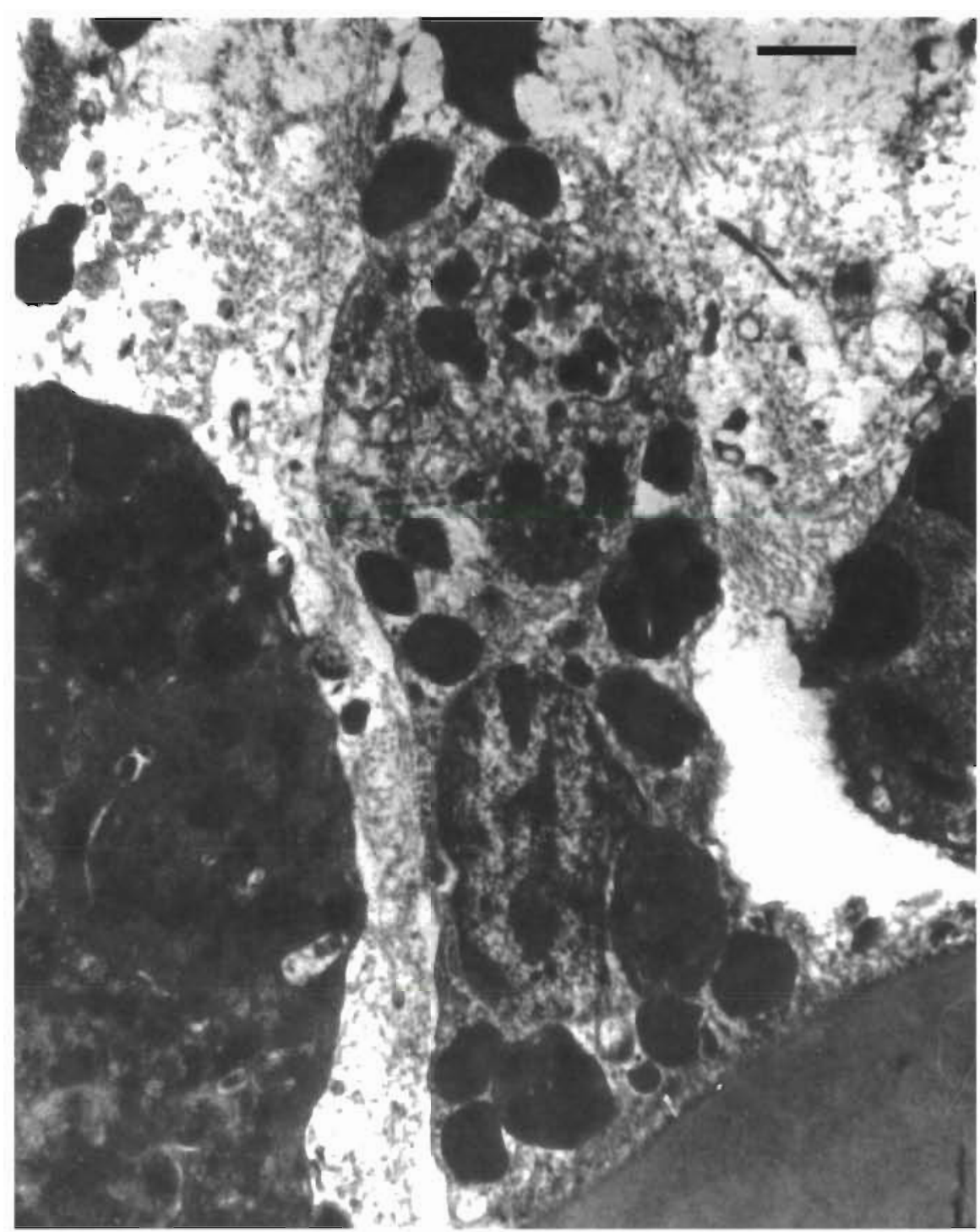

Fig. 10. Limanda Limanda. Light macrophage adhered to a lipid like droplet. Scale bar $=1 \mu \mathrm{m}$

of cell types such as lymphocytes and eosinophilic granular cells was observed. These cell types were also apparent in areas of lesion demonstrating 'scarring', in which the loss of fat cells and macrophages left behind a matrix of collagen. These observations suggest that recovery from the lesions may take place and that lymphocytes and eosinophilic granular cells may be involved in the recovery process. However, the regeneration of adipose tissue was not observed.

The products of the lipid peroxidation process constitute the grossly observable lesion and, consequently, all of the samples examined were of lesions that had entered this stage. As a result it is difficult to establish the sequence of pathological events and in particular the mechanism responsible for initiating the lipid peroxidation process

An analysis of the livers of common dab from the Firth of Forth sites found the concentration of certain insecticide contaminants (hexachlorocyclohexane, a-chlordane and dieldrin) were high in a UK context (Begg 1994). It is known that exposure to xenobiotics can induce oxidative stress in fish and cause lipid peroxidation

presence of extracellular lipopigment in the centre of some of these granulomas. It also seems likely that the granulomas consisting of epitheliod type cells and collagen surrounding lipopigment are the product of continuing necrosis within these macrophage-containing granulomas.

The sequence of events beyond the development of granulomatous lesions is not clear. A cascade of lipid peroxidation reactions is likely once the process has been initiated and probably results in a cyclical process of cell damage, macrophage infiltration, and lipopigment production. This positive feedback process suggests that this condition may be long-lasting and that, once initiated, the progressive development of the lesions is likely. In extensive lesions, which may represent a later stage of development, the infiltration
(Kelly et al. 1998) and lipid peroxidation can result specifically from exposure to dieldrin (Bachkowski et al. 1998), chlordane (Hasoun et al. 1993), and hexachlorocyclohexane (Barros et al. 1991). However, an extensive literature search revealed no studies to indicate the tissue concentration at which induction of oxidative stress takes place in common dab or other fish species and, consequently, the significance of these exposure levels to the development of this condition is unknown.

Oxidative stress can also be induced by a dietary imbalance, usually excess polyunsaturated fatty acids and insufficient vitamin E (Farwer et al. 1994, De Gritz \& Rahko 1995). The resulting pathology, nutritional steatitis, demonstrates histomorphological characteristics identical to those observed in the present study 
and is common in cultured fish (Herman \& Kircheis 1985, Wada et al. 1991, Guarda et al. 1997) and other domestic animals (Brooks et al. 1985, Verschuren et al. 1990). However, there is little overlap in the diets of common and long rough dab (Ntiba \& Harding 1993), which provides some indication against a dietary role in aetiology of steatitis in these species.

Further evidence against a nutritional aetiology comes from the fact that, in cases of nutritional steatitis, lipopigment may be observed within fat cells prior to inflammation (Jolly \& Dalefield 1990). Initiation of lipid peroxidation within the fat cells might also be anticipated as a consequence of xenobiotic-induced oxidative stress, especially if the xenobiotics are lipophilic and assimilated within fat cells. Despite examining a large number of samples, peroxidation in the fat cells was not seen in the present study. This observation suggests that steatitis in common dab is initiated by the necrosis of fat cells with macrophages responding, at least initially, to the constituents of the necrotic fat cells, including lipid. Microbial infection of fat cells has been shown to cause lipid peroxidation and steatitis as a consequence of fat cell necrosis (Hashimoto 1985, Price et al. 1990). Although no infectious agents were detected within the lesions of the common dab, infection of the fat cells prior to the lesion development can not be discounted.

In attempting to establish the aetiology of steatitis in common and long rough dab, efforts should be concentrated on determining the cause of fat cell necrosis, including the possibility of microbial infection and an impact of environmental contaminants.

Acknowledgements. This work was supported by the Department of the Environment. The authors would like to thank Dr Nicolaus Peters, and an anonymous referee for their comments on the manuscript.

\section{LITERATURE CITED}

Al Nafussi AI, Hughes D, Rebello G (1992) Ceroid granuloma of the uterine cervix. Histopathology (Oxf) 21:282-284

Bachowski S, Xu Y, Stevenson DE, Walborg EF, Klaunig JE (1998) Role of oxidative stress in the selective toxicity of dieldrin in the mouse liver. Toxicol Appl Pharmacol 150: 301-309

Bancroft JD, Stevens A (1985) Theory and practice of histological techniques. Churchill Livingstone, Edinburgh

Barros SBM, Simizu K, Junqueira VBC (1991) Liver lipid peroxidation related parameters after short term administration of hexachlorocyclohexane isomers to rats. Toxicol Lett $56: 137-144$

Begg GS (1994) The population ecology of disease in the common dab, (Limanda Limanda L.). PhD thesis, University of Aberdeen

Brooks HV, Rammell CG, Hoogenboom JJL, Taylor DES (1985) Observations on an outbreak of nutritional steatitis (yellow fat disease) in fitch (Mustella putorius furo). $\mathrm{N} \mathrm{Z}$
Vet J 33:141-145

Bruno DW, McVicar AH, Fraser CO (1991) Multiple lipoma in the common dab Limanda limanda L. J Appl Ichthyol 7: $238-243$

Dalefield RR, Jolly RD, Craig AS, Martinus RD, Palmer DN (1987) Age pigment in the thyroid of aged horses. In: Nagy IZ (ed) Lipofuscin-1987: state of the art. Akademiai Kiado, Budapest and Elsevier Science Publishers, Amsterdam, p 213-226

De Gritz BG, Rahko T (1995) Diet induced residual formation in pigs. Gerentology 41:305-315

Elleder M (1991) Primary extracellular ceroid type lipopig ment. A histochemical and ultrastructural study. Biochem J 23:247-258

Farwer SR, Haddeman E, Kivits GAA, Wiersma A, Danse BHJC, Derboer BCJ (1994) The vitamin E nutritional status of rats fed on diets high in fish oil or sunflower seed oil. Br J Nutr 72:127-145

Ghadially FN (1988) Ultrastructural pathology of the cell and matrix. Butterworths, London

Goebel HH (1997) Morphological diagnosis in neuronal ceroid lipofscinosis. Neuropediatrics 28:67-69

Guarda F, Bertoja G, Zoccarato I, Tartari E, Biolatti B (1997) Spontaneous steatitis of epicardial fat in farmed white sturgeon. Aquaculture 158:167-177

Hammer C, Karakiri M (1988) Disease dependent accumula. tion of fluorescent age pigments in the common dab (Limanda limanda Teleostei). In: Nagy IZ (ed) Lipofuscin-1987: state of the art. Akademiai Kiado, Budapest and Elsevier Science Publishers, Amsterdam, p 445-446

Hashimoto I, Tomita $M$, Kohara $T$, Uchino I, Harasima A (1985) Steatitis in mice infected with coxsackie virus B3 Micobiol Immunol 29(4):371-376

Hassoun E, Bagchi M, Bagchi D, Stohs SJ (1993) Comparative studies on the lipid peroxidation and DNA single strand breaks induced by lindane, DDT, chlordane, and endrin in rats. Comp Biochem Physiol Part C Pharmacol Toxicol Endocrinol 104:427-431

Herman RL, Kircheis FW (1985) Steatitis in sunapee trout, Salvelinus alpinus oquassa Girard. J Fish Dis 8:237-239

Jolly RD, Dalefield RR (1990) Lipopigments in veterinary pathology: pathogenesis and terminology. In: Porta EA (ed) Lipofuscin and ceroid pigments. Plenum Press, New York, p 157-168

Kelly SA, Havrilla CM, Brady TC, Abramo KH, Levin ED (1998) Oxidative stress in toxicology: established mammalian and emerging piscine model systems. Environ Health Perspect 106:375-384

Kimura S, Goebel HH (1987) Electron microscopic observation of tonsillar tissue as a diagnostic aid in early juvenile ceroid-lipofuscinosis. Brain Dev 9:593-596

Lange W, Schropp AJN (1985) The morphology of lipopigment granules in oligodendrocytes of the cerebellum and spinal-cord and in schwann-cells of the $\mathrm{N}$-ischiadicus of the cat, Japenese waltzing mouse, and albino mouse. Acta Neuropathol 65:330-334

Maeba R, Shimasaki H, Ueta N, Inoue K (1990) Accumulation of ceroid like pigments in macrophages cultured with phosphatidylcholone liposomes in vitro. Biochim Biophys Acta 1042:287-293

Mitchison MJ, Ball RY, Carpenter KH, Enright JH, Brabbs CE (1990) Ceroid macrophages and atherosclerosis. Biochem Soc Trans 18:1066-1069

Ntiba MJ. Harding D (1993) The food and feeding habits of the long rough dab, Hippoglossoides platessoides (Fabricius 1780) in the North Sea. Neth J Sea Res 31:189-199

Pearse AGE (1985) Histochemistry theoretical and applied, 
Vol 2. Analytical technology, 4th edn. Churchill Livingstone, Melbourne

Price P, Eddy K, Papadimitrio JM, Robertson TA, Shellam GR (1990) Cytomegalovirus infection of adipose tissues induces steatitis in adult mice. Int J Exp Pathol 71:557-571

Raynard RS, McVicar AH, Bell JG, Youngson A, Knox D, Fraser CO (1991) Nutritional aspects of pancreas disease of Atlantic salmon: the effects of dietary vitamin $E$ and polyunsaturated fatty acids. Comp Biochem Physiol 98A(1): 125-131

Editorial responsibility: Nicolaus Peters,

Hamburg, Germany
Triantafyllou A. (1996) Cytological and cytochemical investigations of granular cells in oral lichen planus. J Oral Pathol Med 25:349-355

Verschuren PM, Houtsmuller UMT, Zevenbergen JL (1990) Evaluation of vitamin $E$ requirement and food palatability in rabbits fed a purified diet with a high fish oil content. Lab Anim 24:164-171

Wada S, Hatai K, Kubota S (1991) A histopathological study of cultured striped jack with yellow fat disease. Gyobyo Kenkyu 26(2):61-67

Submitted: January 27, 1999; Accepted: February 8, 2000

Proofs received from author(s): May 29, 2000 